Table 2. SYNTHESIS OF ACETYLChOLINE BY COUPLING CHOLINE ACETYlase WITH THE ACETATE-ACTIVATING ENZYME SYSTEM

\begin{tabular}{|c|c|c|}
\hline Example & Preparation & $\begin{array}{l}\text { Acetylcholine } \\
\text { synthesized } \\
\text { ( } \mu \text { gm./ml. hr.) }\end{array}$ \\
\hline 1 & $\begin{array}{l}\text { Complete system } \\
\text { Choline acetylase }(20 \mathrm{mgm} . / \mathrm{ml} .) \\
\text { Kidney extracts* }(15 \mathrm{mgm} . / \mathrm{ml} \text {.) }\end{array}$ & $\begin{aligned} & 7.5 \\
< & 0.05 \\
< & 0.05\end{aligned}$ \\
\hline 2 & $\begin{array}{l}\text { Complete system } \\
\text { Choline acetylase (20 mgm./ml.) } \\
\text { Kidney extracts* ( } 15 \mathrm{mgm} . / \mathrm{ml} \text {.) }\end{array}$ & $\begin{array}{r}12 \cdot 5 \\
0.07 \\
<0.05\end{array}$ \\
\hline 3 & $\begin{array}{l}\text { Complete system } \\
\text { Choline acetylase }(20 \mathrm{mgm} . / \mathrm{ml} .) \\
\text { Escherichia coli extracts }(40 \mathrm{mgm} . / \mathrm{ml} \text {.) }\end{array}$ & $\begin{aligned} & 9 \cdot 5 \\
< & 0.05 \\
< & 0.05\end{aligned}$ \\
\hline
\end{tabular}

Details as in Table 1, except enzyme source. Figures in parentheses indicate the amount of freeze-dried tissue powder used.

* 20-40 gm./dl. fraction of ammonium sulphate was used.

Table 3. SYNThesis of ACETYLChOLINE FRoM ChoLINe AND ACETYLCOENZYMe $\boldsymbol{A}$ by Choline ACETYLASE

\begin{tabular}{|c|l|c|}
\hline & Acetyl-coenzyme $A$ yielded by & $\begin{array}{c}\text { Acetylcholine } \\
\text { synthesized } \\
(\mu \mathrm{gm} . / \mathrm{ml} .)\end{array}$ \\
\hline 1 & $\begin{array}{l}\text { Guinea pig kidney }(75 \mathrm{mgm} .) \\
\text { Escherichia coli }(45 \mathrm{mgm})\end{array}$ & $\begin{array}{c}4 \cdot 25 \\
2 \cdot 20\end{array}$ \\
\hline
\end{tabular}

Each sample contained $4 \mu M$ choline, $8 \mu M$ cysteine, $3 \mu M$ phosphate and acetyl-coenzyme $\boldsymbol{A}$. Extract of freeze-dried powder of kidney or Escherichia coli was incubated with adenosine triphosphate, coenzyme $A$, potassium and magnesium ions, cysteine and acetate at $37^{\circ} \mathrm{C}$. After $90 \mathrm{~min}$. incubation, the mixture was acidifled to $p \mathrm{H} 3.5$ and heated at $80^{\circ} \mathrm{C}$. for 2 min. From this mixture active acetate or acetylcoenzyme $A$ was prepared by the method of Littlefield et al. (ref. 4) Figures in parentheses indicate the weight of the freeze-dried tissue used.

shown to synthesize $0.5 \mathrm{mgm}$. of acetylcholine an hour when coupled with the acetate-activating enzyme system.

In the course of preparing choline acetylase, it is worth noticing that the supernatant still contained a considerable amount of the citrate-activating system, after the first acidification in the preparation of choline acetylase, though the acetate-activating system had already been excluded almost completely.

Further purification of choline acetylase is now in progress ; details of the present experiment will be published elsewhere.

Department of Pharmacology,

H. KUMAGAI

S. EBASHI

University of Tokyo

Bunkyo-ku, Tokyo.

Nov. 25

${ }^{3}$ Balfour, W. E., and Hebb, C., J. Physiol., 118, 94 (1952).

2 Kumagai, H., Ebashi, S., and Takeda, F., Folia Pharmacologica Japonica, 48, 211P (1952).

${ }^{3}$ Chou, T. C., and Lipmann, F., J. Biol. Chem., 196, 89 (1952).

'Littlefleld, J. W., and Sanadi, D. R., J. Biol. Chem., 200, 65 (1953).

\section{Evidence for the Occurrence of Glucose Dehydrogenase in Yeast}

WHEN buffered suspensions of washed bakers' yeast are incubated anaerobically with methylene blue, dehydrogenase activity as measured by the rate of decolorization is greater with glucose than it is with other substrates. While investigating the action of nicotine on various dehydrogenase systems, including those of yeast, we found that, whereas nicotine inhibited dehydrogenase activity of Saccharomyces cerevisiae with glucose, activation resulted with glucose-6-phosphate as substrate.
For these experiments we used cells harvested from young - not more than one day old-actively growing cultures. Before preparing the final suspensions in phosphate buffer, they were washed and aerated in suspension for two hours at $37^{\circ}$ to reduce the dehydrogenase activity due to endogenous metabolites. Dehydrogenase activities in the presence of added substrate and triphenyltetrazolium bromide were measured at $30^{\circ}$ and $p \mathbf{H} 7.5$ by the method of Fahmy and Walsh'.

For experiments using glucose-6-phosphate as substrate the cell membranes were first ruptured by alternately freezing and thawing, as the substrate was otherwise unable to penetrate the cells. Experiments showed that this procedure, though reducing dehydrogenase activity with glucose, did not influence the effect of nicotine; thereby demonstrating that the inhibitory action of nicotine was not due to its preventing the substrate from entering the cell.

Inhibitions up to 20 per cent by nicotine $(0.01 \mathrm{M})$ were recorded with glucose. Activations up to 40 per cent by nicotine $(0.01 M)$ were recorded with glucose-6-phosphate.

In view of these results, it became of interest to investigate the effect of nicotine on the hexokinase reaction. Partially purified hexokinase ${ }^{2,3}$ was prepared from yeast. Activities were measured at $30^{\circ}$ in bicarbonate buffer, $p H \mathbf{H \cdot 5}$, by the method of Colowick and Kalckar ${ }^{3}$ using the Warburg apparatus. Nicotine $(0.01 M)$ had no effect on the transfer of phosphate from adenosine triphosphate to glucose.

The significance of these findings is best appreciated by reference to the diagram.

glucose- $($ inhibition)
glucose-6-phosphate $\stackrel{\text { (activation) }}{\rightarrow}$ gluconic acid
Effects of nicotine on the enzymic reactions are indicated in brackets.

Fluoride $(0.01 M)$, which does not inhibit hexokinase $^{4}$ or glucose-6-phosphate dehydrogenase ${ }^{5}$, inhibits glucose dehydrogenase activity of yeast by 30-40 per cent.

So far as we are aware, glucose dehydrogenase has not hitherto been reported as occurring in yeast.

In its behaviour towards nicotine, we find that the glucose dehydrogenase activity of yeast resembles that of the enzyme ${ }^{6}$ in mammalian liver. Liver glucose dehydrogenase was prepared and purified by the method of Brunelli and Wainio? ${ }^{7}$ Its activity was measured by determining the oxygen uptake of a system containing, in addition to the enzyme, glucose, codehydrogenase I, Straub's heart flavoprotein $^{8}$ and methylene blue. Nicotine $(0.01 M)$ inhibited by 15-18 per cent.

Glucose dehydrogenase activity, similarly inhibited by nicotine, occurs also in Torulopsis utilis.

\section{A. R. FAHMY}

E. O'F. WALSH

Royal Free Hospital School of Medicine,

London.

Feb. 1.

${ }^{1}$ Fahmy, A. R., and Walsh, E. O'F., Biochem. $J$., 51, 55 (1952).

${ }^{2}$ Meyerhof, O., Biochem. Z., 183, 186 (1927).

${ }_{3}$ Colowick, S. P., and Kalckar, H. M., J. Biol. Chem., 148, 117 (1943).

${ }^{4}$ Berger, L., Slein, M. W., Colowick, S. P., and Cori, C. F., J. Gen. Physiol., 29, 379 (1946).

${ }^{5}$ Dickens, F., and Glock, G. E., Biochem. J., 50, 92 (1952).

- Harrison, D. C., Biochem. J., 25, 1016 (1931).

${ }^{7}$ Brunelli, E., and Wainio, W. W., J. Biol. Chem., 17\%, 75 (1949).

${ }^{8}$ Straub, F. B., Biochem. J., 33, 787 (1939). 